\title{
The role of science in COVID-19: a brief essay for a deep reflection
}

\section{O papel da ciência na COVID-19: um breve ensaio para uma profunda reflexão.}

DOI: $10.46919 / \operatorname{archv2n3-013~}$

Recebimento dos originais: 01/01/2021

Aceitação para publicação: 31/03/2021

\author{
Rafael Gomes Bastos \\ Universidade Federal de Juiz de Fora (UFJF), Faculdade de Medicina, Juiz de Fora, MG, Brasil. \\ E-mail: rafaelfreeway@ hotmail.com \\ Carlos Alberto Mourão Júnior \\ $\mathrm{MD}, \mathrm{PhD}$ \\ Universidade Federal de Juiz de Fora (UFJF), Departamento de Fisiologia, Juiz de Fora, MG, Brasil. \\ E-mail: camouraojr@gmail.com
}

\begin{abstract}
The COVID-19 pandemic created a polarization of opinions and behavior. Both sides say they are arm in arm with science. This short essay aims to provoke a reflection in the reader about the epistemological foundations of science, especially in moments of high uncertainty, such as in a pandemic.
\end{abstract}

Keywords: COVID-19; SARS-CoV-2, Pandemic, Epistemology, Philosophy of Science.

\section{RESUMO}

A pandemia da COVID-19 criou uma polarização de opiniões e condutas. Ambos os lados, dizem estar de braços dados com a ciência. Este pequeno ensaio tem por objetivo provocar uma reflexão no leitor acerca dos fundamentos epistemológicos da ciência, principalmente em momentos de elevada incerteza, como em uma pandemia.

Palavras-Chave: COVID-19, SARS-CoV-2, Pandemia, Epistemologia, Filosofia da Ciência.

\section{ESSAY}

We attended catholic schools in the countryside of Brazil. These schools, founded by religious, had, as their motto, the aphorism: Fides et scientia, that is, Faith and Science. We learned from an early age that we should believe in science and have faith in its principles. We still remember the days that there were no classes because a doctor would come to the school and talk to us. After his speech, many students decided to go to medical school. We were inspired and motivated to help people and to do no harm.

Years passed, and last week we attended an online meeting with some local doctors. The host was one of the doctors who inspired us 30 years before. This well-known physician, now in his seventies, is someone we have always admired as a bright and insightful doctor. But we were taken aback when he told us that a middle-aged doctor with no comorbidities he knew had died. Asking further, he told us that she 
was diagnosed with COVID-19, was not given the so-called "early treatment" and eventually died in a few weeks, although she received the best possible medical care, in one of the most equipped hospitals in the country, as she was a well-known and, respected doctor who had an abundant financial resource. He was convinced that had she received early treatment she would have survived. He went as far as to say that she had been murdered because she did not receive early treatment. The early treatment for COVID-19 saves lives, he said. He was adamant.

Rarely have we seen such a heated debate between the so-called "scientific truth" and those who dare to deny it. On the one hand, there are world leaders who claim to strictly follow science in their decision-making process. On the other one, there are politicians who say they know better. Instead of picking a side, we wish to discuss why science may or may not be trusted and, if so, how deep the scientific bases are. Moreover, what lessons can we and science practice learn from COVID-19?

The NIH (National Institute of Health, USA) defines scientific rigor as "the strict application of the scientific method to ensure robust and unbiased experimental design, methodology, analysis, interpretation and reporting of results. This includes full transparency in reporting experimental details so that others may reproduce and extend the findings" (1). Although we know how it should be, it goes without saying that reality might be slightly different.

First of all, one can argue that unbiased experimental designs are, albeit perfect in theory, unreachable. To be human is to be biased. The golden rush for publications, which is the order of the day in most universities, is at an all time high. Scientific articles about COVID-19 are welcome in most peerreviewed journals. Although we believe that some of these articles are genuine and strictly follow the possible scientific rigor, it should be pointed out that some researchers are more interested in their curriculum rather than the scientific methodology.

Secondly, unlike natural sciences, biological sciences are uncertain. To be fair, even in natural sciences the element of uncertainty is found too often when one goes deeper into quantum mechanics. Nearly one hundred years ago, Werner Heisenberg, a German physicist, stated that the more precisely the position of some particles is determined, the less precisely its momentum can be predicted. It became known as the Uncertainty Principle (2). One of the first lessons young doctors learn is that patients hardly ever meet the criteria for a certain diagnosis. Learning how to deal with uncertainty in medicine is as useful as painful. We try to tame the lack of certainty with statistics and controlled trials but, much to our dismay, success is very often followed by failure. One of the reasons for that may lie in the very process of the scientific method.

Sir Karl Popper, the famous Austrian-British philosopher once stated that "science does not rest upon solid bedrock. The bold structure of its theories rises, as it were, above a swamp. It is like a building erected on piles. The piles are driven down from above into the swamp, but not down to any natural or 
'given' base; and if we stop driving the piles deeper, it is not because we have reached firm ground. We simply stop when we are satisfied that the piles are firm enough to carry the structure, at least for the time being" (3). If one breaks down Popper's sentence one can see that right at the beginning he makes it very clear that science is not set in stone. To the best of our knowledge this can be understood in two different ways: a) the element of uncertainty is at the core of science and b) it changes $(4,5)$.

In a very famous speech at the Savoy in London in 1930 George Bernard Shaw claimed that the difference between science and religion is that although the former consists of current people proving old people wrong, the latter lies in the principle that old people were right and there is no reason to change that (6). This is a fundamental distinction between science and religion. It seems to us that those who claim passionately that the early treatment for COVID-19 is the solution for the disease might be ignoring the fact that we have not had enough time to study it deeply and it is still uncertain to say the least. Instead of taking a scientific approach, they may be taking a religious one.

Albert Einstein who was also at the Savoy in 1930 said that "One thing I have learned in a long life: that all our science, measured against reality, is primitive and childlike - and yet it is the most precious thing we have." (7)

It seems to us that COVID-19 ought to be studied and that time is of the essence as many lose their lives to this virus every day. However, let us not forget that, as the poet Alexander Pope said: "fools rush in where angels fear to tread" (8), we must bear in mind that we are still walking on a swamp at night time. We may have to dig deeper before we can make conclusions. When in doubt between fides et scientia, it might be wise to remember that, almost always, In medio est virtus, and, nowadays, In medio est Virus... 


\section{CONSULTED BIBLIOGRAPHY}

1. Hofseth LJ. Getting rigorous with scientific rigor. Carcinogenesis. 2018;39(1):21-5.

2. Heisenberg W. Physics and philosophy: the revolution in modern science: Harper \& Row Publishers; 1962.

3. Popper KR. The logic of scientific discovery. London: Routledge; 2002 [1935].

4. Popper KR. Conjectures and refuttions: the growth of scientific knowledge. New york: Basic books; 1962.

5. Popper KR. Objective knowledge: an evolutionary approach. Oxford: Clarendon Press; 1994 [1972].

6. Gibbs AM. Bernard Shaw: a life. Gainesville: University Press of Florida; 2005.

7. Calaprice A. The ultimate quotable Einstein. Princeton: Princeton University Press; 2013.

8. Pope A. An essay on criticism. Cambridge: Cambridge University Press; 2014 [1711]. 